\title{
A meta-analysis of the efficacy of azithromycin and benzathine penicillin in early syphilis
}

\author{
Hai-Ying Li ${ }^{1,2}$, Hui-Qing Qu ${ }^{3}$, Xiu-Min Wang ${ }^{2}$, Yu-Jie Zhang ${ }^{2}$, Fu-Ren Zhang ${ }^{1,4 \star}$ \\ ${ }^{1}$ Department of Dermatology, Shandong Provincial Hospital for Skin Diseases, Shandong University, Jinan, Shandong, 250022, \\ ${ }^{2}$ Department of Dermatology, ${ }^{3}$ Department of Blood Transfusion, The Affiliated Hospital of Binzhou Medical University, Binzhou, \\ Shandong, 256600, ${ }^{4}$ Department of Dermatology, Shandong Provincial Institute of Dermatology and Venereology, Shandong \\ Academy of Medical Sciences, Jinan, Shandong, 250022
}

*For correspondence: Email: q_w_1726@sina.com

\begin{abstract}
Purpose: To systematically analyze the efficacy of azithromycin and benzathine penicillin in early syphilis, and provide guidance for diagnosis and treatment.

Methods: Databases were searched for randomized controlled trials (RCTs) and control studies according to keywords, and inclusion and exclusion criteria. Related documents and meeting records were also searched manually to extract study types, basic information of study objects, intervention measurements and study results, and evaluation of the quality of the methodology used.

Results: Three studies were excluded from the review. The quality evaluation was $B$ grade, and heterogenicity was good. We adopted a fixed effect model to conduct the meta-analysis. There was no significant difference in the cure rate between azithromycin and benzathine penicillin administered for 6 months. The ORs for 3 time points were $0.96(95 \% \mathrm{Cl}=0.71,1.29), 0.01(95 \% \mathrm{Cl}=-0.05,0.06)$, and $0.04(95 \% \mathrm{Cl}=-0.02,0.11 ; p<0.05)$. There were no significant differences in the incidence of adverse events among the three studies.

Conclusion: There was no apparent difference in the efficacy of azithromycin and benzathine penicillin in early syphilis. The advantages of azithromycin included good compliance, a long half-life, and a high economic benefit.
\end{abstract}

Keywords: Early syphilis, Azithromycin, Benzathine penicillin, Curative effect

\begin{abstract}
This is an Open Access article that uses a funding model which does not charge readers or their institutions for access and distributed under the terms of the Creative Commons Attribution License (http://creativecommons.org/licenses/by/4.0) and the Budapest Open Access Initiative (http://www.budapestopenaccessinitiative.org/read), which permit unrestricted use, distribution, and reproduction in any medium, provided the original work is properly credited.
\end{abstract}

Tropical Journal of Pharmaceutical Research is indexed by Science Citation Index (SciSearch), Scopus, International Pharmaceutical Abstract, Chemical Abstracts, Embase, Index Copernicus, EBSCO, African Index Medicus, JournalSeek, Journal Citation Reports/Science Edition, Directory of Open Access Journals (DOAJ), African Journal Online, Bioline International, Open-J-Gate and Pharmacy Abstracts

\section{INTRODUCTION}

The effectiveness of a single dose of benzathine penicillin for early syphilis by muscle injection has been confirmed because of the low cost and good compliance; however, the disadvantages include pain caused by a high-dose deep intramuscular injection, drug allergy, disposable injection equipment, related personnel training, and the risk for transmission of bloodborne disease pathogens. It is thus necessary to research and develop an effective and welltolerated single dose oral medication [1-3]. Azithromycin is a macrolide antibiotic which has a tissue half-life of $70 \mathrm{~h}$. It has been reported that azithromycin can effectively control infections 
involving Bedsonia trachomatis, Neisseria gonorrhoeae, and Haemophilus ducreyi [4,5]. Therefore, we conducted a systematic review on the curative effect of azithromycin and benzathine penicillin on early syphilis based on existing randomized controlled studies.

\section{METHODS}

\section{Literature search}

The following keywords were searched for in this study: "early syphilis;" "benzathine penicillin;" and "azithromycin." The timeframe for the selected documents was January 1975-December 2015. The Medline, Embase, and Cochrane Library databases were searched. The search also included paper documents, meeting minutes, and reference documentation.

\section{Data selection}

In the current study, publications were considered eligible for inclusion if the following inclusion criteria were met: (1) randomized controlled trial; (2) English literature; (3) oral azithromycin treatment; (4) > 18 years of age; and (5) evaluated the cure rate, and the skin rash improved or faded and the rapid plasma reagin test was negative during follow-up evaluation. All of the relevant content in this study was made available and agreed to by the Ethics Committee of our hospital. The literature was independently screened by two authors. When the authors disagreed, the difference was settled through negotiation or a third author participated in the deliberation and decision if necessary.

\section{Data extraction}

Data extraction was independently performed by two researchers from the included studies. The cases were separately analyzed for serologic cure and adverse reactions. Intentionto-treat analysis was used to calculate the loss rate based on the last follow-up.

\section{Statistical analysis}

The odds ratio (OR) was calculated for successfully treating early syphilis by azithromycin and benzathine penicillin in each study. Studies with incomplete follow-up records were excluded. Statistical significance is represented as the OR and $95 \%$ confidence interval $(\mathrm{Cl})$. We used a fixed effects model and unified OR values that were detected by chisquare tests. Errors might exist in the evaluation results due to hierarchical meta-analysis. Data were stratified by different subgroups, including the follow-up time point, different stages of early syphilis, and different doses of azithromycin. Pvalues $<0.05$ were considered statistically significant.

\section{RESULTS}

\section{Included documents}

There were three documents excluded based on keywords, inclusion criteria, and exclusion criteria. To evaluate the generation of assigned sequences in randomized controlled trials, a blinded method, integrity of data statistics, and selective reporting according to risk bias assessment methods were used as reported in the literature. The results showed that the research quality evaluation of the three studies were B grade. There were 919 patients included in the analysis from studies published between 2001 and 2010 with follow-up 1, 3, 6, and 9 months after treatment. Follow-up content included adverse events after treatment and serology detection. The flow figure of document selection is shown in Figure 1. The content abstract of the included documents is shown in Table 1.

\section{Forest map meta-analysis}

The time point of selection was 3,6 , and 9 months after treatment. The data from three studies were compared and analyzed. Heterogeneity analysis showed a $p>0.05$ of the three times points. A fixed effect model was used for meta-analysis. The OR value of the 3 times points was $0.96(95 \% \mathrm{Cl}=0.71,1.29), 0.01$ $(95 \% \mathrm{Cl}=-0.05,0.06)$, and $0.04(95 \% \mathrm{Cl}=-$ $0.02,0.11 ; p>0.05)$. Because diamond and vertical lines intersected with each other, there was no significant difference in the efficacy among the 3 drugs 2 and 6 months after treatment. One study had 9 months of healing data missing and the bias of the diamond was apparent. Therefore, a further analysis for the cure rate 9 months after treatment was necessary (Figure 2).

\section{Time of adverse reactions}

With respect to adverse reactions, azithromycinassociated gastrointestinal discomfort was a common phenomenon, which always occurred 1 - 2 weeks after treatment. The main adverse events in patients were fever, vomiting, diarrhea, and ulcers. There was no significant difference in the incidence of adverse reactions for two drugs, which occurred in the included studies. The early reports of Hook showed that although the azithromycin-induced indigestion event rate was 


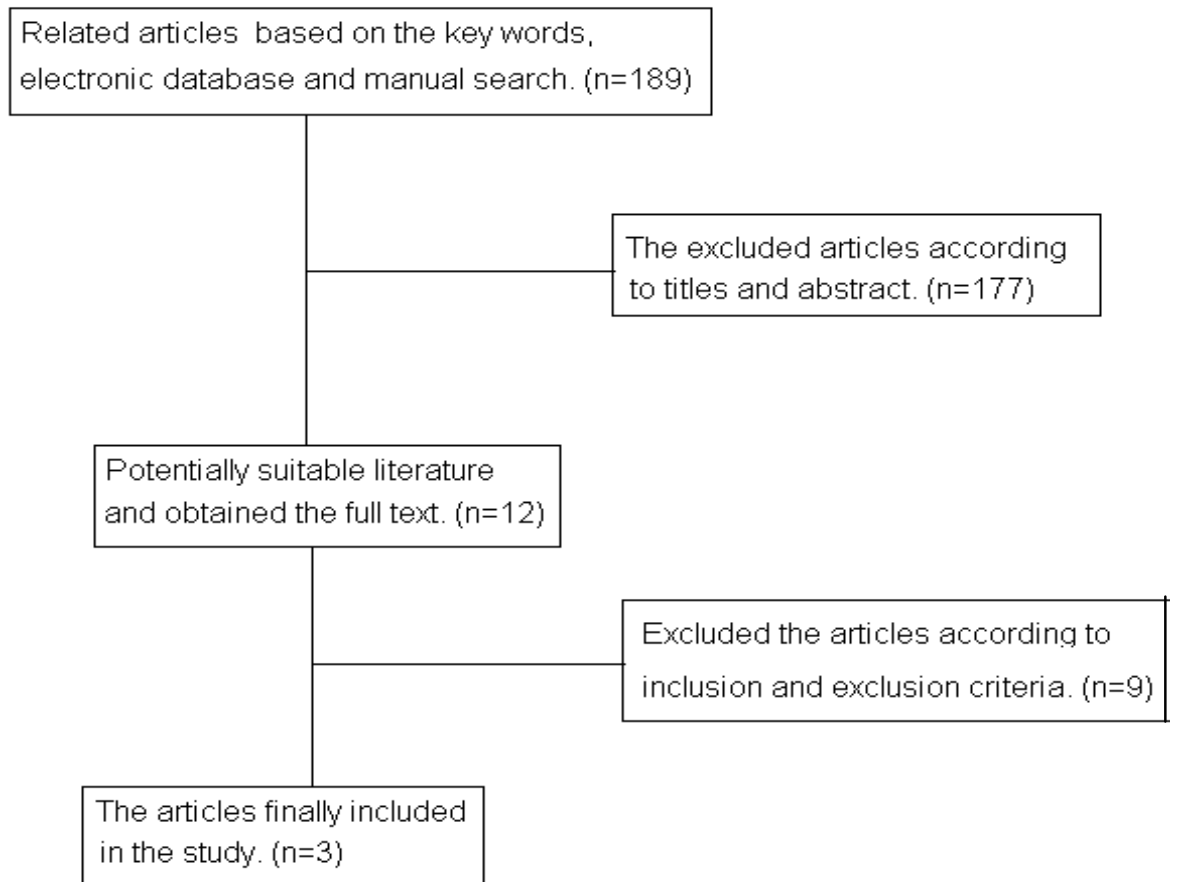

Figure 1: Document retrieval and flow figure for document selection

5 times that of benzathine penicillin; there was no obvious different between azithromycin and benzathine penicillin $(\mathrm{RR}=4.75 ; 95 \% \mathrm{Cl}=0.67-$ 33.9; $P=0.09)[6-8]$. The funnel chart analysis for published bias could not be carried out because of the small size of studies included in the study.

\section{DISCUSSION}

Based on the current meta-analysis, there was no significant difference in the 6-month cure rate between azithromycin and benzathine penicillin in patients with early syphilis. The interference of system and random error led to bias in the results. The analysis of follow-up time, staging of disease, dosage of azithromycin, and other variables showed that obvious systematic error did not exist. The results of pooled analysis were well-distributed, which implied that the magnitude of the random error was not as large as expected. Azithromycin did not show a higher cure rate than benzathine penicillin, which was consistent with past studies [9]. At present, there is still a lack of data on the cure rate of syphilis in the second stage and latent phase. Therefore, future studies should be conducted to improve the procedure.

A random experiment directly comparing the side effects between azithromycin and benzathine penicillin, including Jarisch-Herxheiner reaction and digestive discomfort, did not exist in past studies $[10,11]$. Some studies have reported that the adverse reaction rate of azithromycin is five times that of benzathine penicillin, but there was no apparent statistical difference $[9,11]$. Patient compliance was one of the most important factors in considering treatment decisions. Benzathine penicillin is always dosed twice daily, while azithromycin is a once per day regimen. Because patients tend to be prescribed azithromycin and there was no significant difference in the effect of two drugs, some studies regard azithromycin as the preferred drug $[12,13]$.

Combined with the characteristics of the 60-h half-life of azithromycin, satisfactory serum concentrations could be maintained by taking azithromycin one time per day. There was no significant difference between the effect of early syphilis and benzathine penicillin based on the analysis of the ratio of different doses of azithromycin. It has been suggested that treatment with penicillin and partial compliance can effectively control early syphilis; however, dose-response tests should confirm the findings.

The clinical cost differences between single and repeated doses always play an important role in therapeutic decision-making under the premise of limited resources. The treatment of uncomplicated genital syphilis infections is controversial [14]. Azithromycin has been patented for > 10 years in the United States, and benzathine penicillin is inexpensive. The corresponding cost for benzathine penicillin also 
Table 1: Abstract of included articles

\begin{tabular}{|c|c|c|}
\hline \multirow{3}{*}{ Hook et al [6] } & $\begin{array}{l}\text { Study } \\
\text { objective }\end{array}$ & $\begin{array}{l}74 \text { patients were divided into three groups: benzathine penicillin group, } 2.0 \mathrm{~g} \text { azithromycin } \\
\text { group and } 4.0 \mathrm{~g} \text { azithromycin group. The overall male and female proportion was } 11: 9 \text {. The } \\
\text { average age of patients in these three groups was } 29 \text { years (range, } 18-49 \text { years), } 33 \text { years } \\
\text { (range, } 18-56 \text { years), and } 28 \text { years (range, } 18-49 \text { years). The follow-up time of } 81 \% \\
\text { patients was equal to or greater than } 3 \text { months. The study time period was from October } \\
1995 \text { to December } 1997 .\end{array}$ \\
\hline & $\begin{array}{l}\text { Intervention } \\
\text { measurement }\end{array}$ & $\begin{array}{l}\text { The patients in these three groups received } 2.4 \text { million unit intramuscular injection of } \\
\text { benzathine penicillin } 1 \text { or } 2 \text { times, took } 2.0 \mathrm{~g} \text { azithromycin orally } 1 \text { or } 2 \text { times, and the time } \\
\text { interval was about } 1 \text { week. Follow-up evaluations occurred } 1 \text { week, } 2 \text { weeks, and } 1,3,6,9 \text {, } \\
\text { and } 12 \text { months after treatment. The follow-up content included sexual history, serologic } \\
\text { evaluation, and evaluation of the recurrence of syphilis. }\end{array}$ \\
\hline & Results & $\begin{array}{l}94 \% \text { of patients }(16 / 17) \text { in the azithromycin }(2.0 \mathrm{~g}) \text { group had serologic improvement. } \\
\text { Compared with the benzathine penicillin group, there was no obvious difference in the cure } \\
\text { rate until the end of follow-up ( } \mathrm{RR}=0.97 ; 95 \% \mathrm{Cl}, 0.74-1.27 ; \mathrm{P}=0.75) .83 \% \text { of patients in the } \\
\text { azithromycin }(2.0 \mathrm{~g}) \text { group had serologic improvement, compared with the benzathine } \\
\text { penicillin group, there was no obvious difference in the cure rate }(\mathrm{RR}=0.88 ; 95 \% \mathrm{Cl}, 0.72- \\
1.08 ; \mathrm{P}=0.95) \text {. The probability of gastrointestinal discomfort of the patients in the } \\
\text { azithromycin group was higher compared with benzathine penicillin; the probability of } \\
\text { adverse events for these two drugs was } 17 \% \text { and } 24 \% \text { respectively. }\end{array}$ \\
\hline \multirow{3}{*}{ Riedner et al [7] } & $\begin{array}{l}\text { Study } \\
\text { objective }\end{array}$ & $\begin{array}{l}\text { The study time period was September - March } 2000 \text {. There were } 328 \text { patients, and the } \\
\text { average age was } 27 \text { years (range, } 15 \text { - } 60 \text { years). The male-to-female ratio was } 93: 235 ; \\
50.3 \% \text { of the patients received benzathine penicillin treatment and } 49.7 \% \text { of the patients } \\
\text { received azithromycin treatment. }\end{array}$ \\
\hline & $\begin{array}{l}\text { Intervention } \\
\text { measurement }\end{array}$ & $\begin{array}{l}\text { Patients in the } 2 \text { groups received a } 2.4 \mathrm{M} \mathrm{U} \text { intramuscular injection of benzathine penicillin } \\
\text { or azithromycin } 2.0 \mathrm{~g} \text { orally. The follow-up time points were } 3,6 \text {, and } 9 \text { months after } \\
\text { treatment. The follow-up content included serologic evaluation and adverse events. }\end{array}$ \\
\hline & Results & $\begin{array}{l}\text { The cure rate of benzathine penicillin and azithromycin at three times points were as } \\
\text { follows: } \\
59.4 \%(95 \% \mathrm{Cl}, 51.8-67.1) \text { versus } 59.5(95 \% \mathrm{Cl}, 51.8-67.3) ; 85.5 \%(95 \% \mathrm{Cl}, 79.4-90.6) \\
\text { versus } 81.5(95 \% \mathrm{Cl}, 74.8-87.4) \text {; and } 98.3 \%(95 \% \mathrm{Cl}, 94.5-99.7) \text { versus } 96.5(95 \% \mathrm{Cl}, 92.0- \\
\text { 98.8). There was no obvious difference in the incidence of adverse events between the two } \\
\text { groups. }\end{array}$ \\
\hline \multirow{3}{*}{ Hook et al [8] } & $\begin{array}{l}\text { Study } \\
\text { objective }\end{array}$ & $\begin{array}{l}\text { The study time period was June } 2000 \text {-March } 2007 \text {. There were } 517 \text { patients; the average } \\
\text { age was } 27 \text { years, and the male-to-female ratio was } 313: 204.262 \text { patients received } \\
\text { benzathine penicillin treatment and } 255 \text { patients received azithromycin treatment. }\end{array}$ \\
\hline & $\begin{array}{l}\text { Intervention } \\
\text { measurement }\end{array}$ & $\begin{array}{l}\text { Two groups of patients received a } 2.4 \mathrm{M} U \text { intramuscular injection of benzathine penicillin } \\
\text { and } 2.0 \mathrm{~g} \text { of oral azithromycin treatment. The follow-up time points were } 1 \text { week, } 2 \text { weeks, } \\
\text { and } 3 \text { months and } 6 \text { months after treatment. The follow-up content included serologic } \\
\text { evaluation and adverse events. }\end{array}$ \\
\hline & Results & $\begin{array}{l}\text { By the end of the follow-up period, the percentage of azithromycin and benzathine penicillin } \\
\text { that reached the serologic cure standard was } 77.6 \% \text { and } 78.5 \% \text {, respectively (lower limit of } \\
\text { the } 95 \% \mathrm{Cl}, 7.2 \%) \text {. The corresponding incidence of adverse events was } 61.5 \% \text { and } 46.3 \% \text {, } \\
\text { respectively. }\end{array}$ \\
\hline
\end{tabular}

includes the cost of a needle and syringe. The results of two studies $[15,16]$ on the cost effectiveness of antibiotics showed that azithromycin had a superior cost-benefit, while statistical analysis of the cost of the corresponding drugs has not been performed in published studies. Considering the assumption is not accurate, a comprehensive cost-benefit analysis should be conducted.

Compared with the 2.4 M U dose of benzathine penicillin, azithromycin is effective in controlling early syphilis. There were no obvious differences in adverse reactions. Therefore, a further dosage-reaction test evaluation plan for azithromycin is needed. Combined with other related study results, when the hidden trouble exists or the patients cannot tolerate during benzathine penicillin use. Azithromycin can be regarded as a good replacement therapy drug. Therefore, it is necessary to conduct a further study on the effect of benzathine penicillin in early syphilis, enhance the accuracy of the results, and provide guiding clinical significance.

However, there were some limitations in this study, including the insufficient inclusion of the literature and lack of strength of evidence. Therefore, it is necessary to compare and analyze more randomized controlled trials in a future study.

\section{CONCLUSION}

The findings show that there is no obvious difference between azithromycin and benzathine 


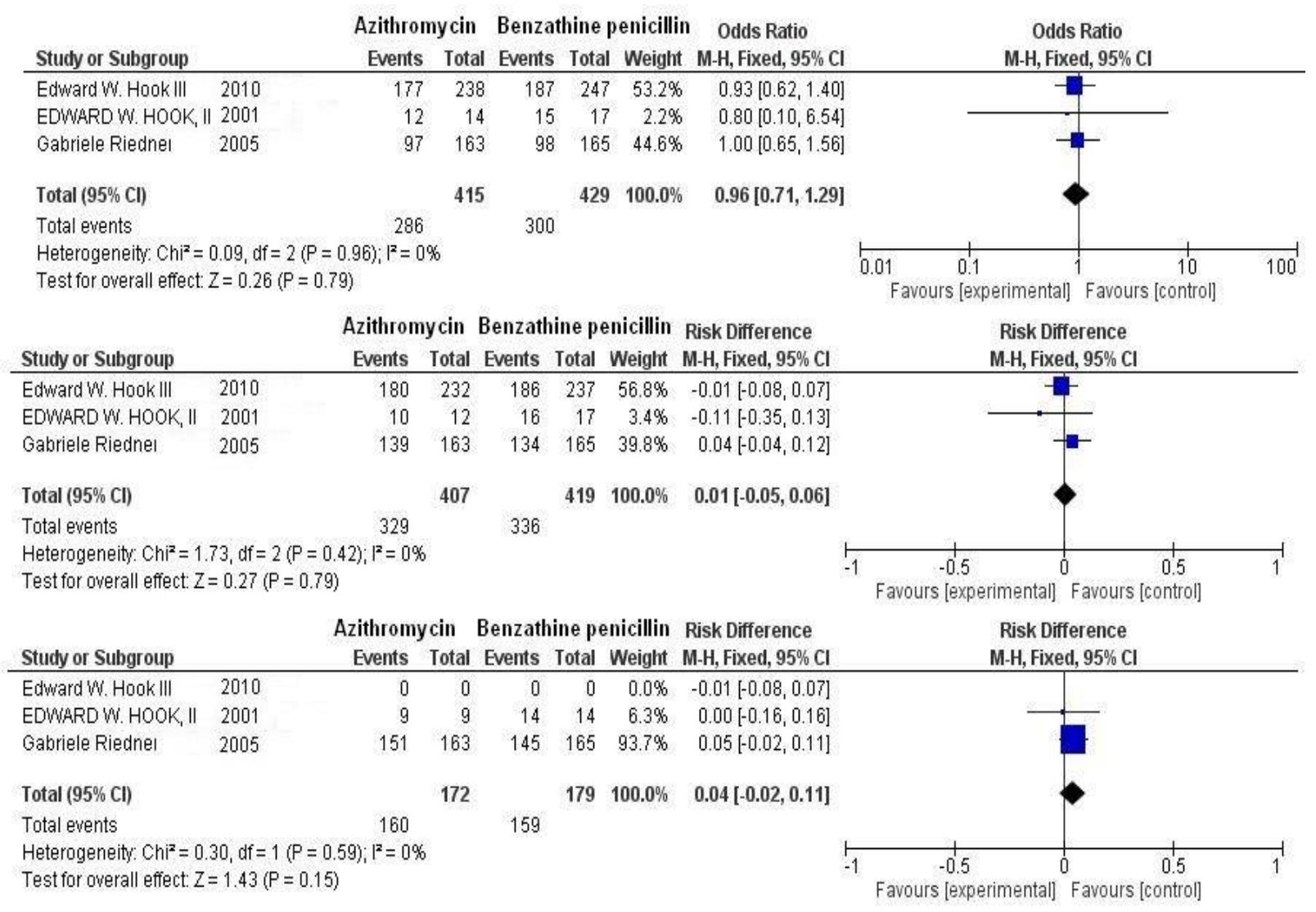

Figure 2. Forest map meta-analysis of the three times points

penicillin in terms of their therapeutic effect on early syphilis. However, azithromycin has the advantages of good compliance, long half-life and lower cost. Therefore, its likelihood for application in clinical practice may be greater.

\section{DECLARATIONS}

\section{Acknowledgement}

This study was supported by the Foundation of Research on Technology and Quality Standards of Mixture Formula for Regulating Stomach and Releasing Excessive Turbid (no. ZRQN1509, 030029031 to Wei Jin).

\section{Conflict of Interest}

No conflict of interest associated with this work.

\section{Contribution of Authors}

We declare that this work was done by the authors named in this article and all liabilities pertaining to claims relating to the content of this article will be borne by the authors. Hai-Ying $\mathrm{Li}$ designed the study and wrote the paper. HuiQing Qu, Xiu-Min Wang, and Yu-Jie Zhang collected and analyzed the data. Fu-Ren Zhang reviewed the full text and proofread the manuscript.

\section{REFERENCES}

1. Parkes R, Renton A, Meheus A, Laukamm-Josten U. Review of current evidence and comparison of guidelines for effective syphilis treatment in Europe. Int $J$ STD AIDS. 2004; 15(2): 73-88.

2. Martin DH, Mroczkowski TF, Dalu ZA, McCarty J, Jones RB, Hopkins SJ, Johnson RB. A controlled trial of a single dose of azithromycin for the treatment of chlamydial urethritis and cervicitis. The Azithromycin for Chlamydial Infections Study Group. N Engl J Med. 1992; 327(13): 921-925.

3. Handsfield HH, Dalu ZA, Martin DH, Douglas JM Jr, McCarty JM, Schlossberg D. Multicenter trial of singledose azithromycin vs. ceftriaxone in the treatment of uncomplicated gonorrhea. Azithromycin Gonorrhea Study Group. Sex Transm Dis. 1994; 21(2): 107-111.

4. Martin DH, Sargent SJ, Wendel GJ, McCormack WM, Spier NA, Johnson RB. Comparison of azithromycin and ceftriaxone for the treatment of chancroid. Clin Infect Dis. 1995; 21(2): 409-414.

5. Hook ER, Stephens J, Ennis DM. Azithromycin compared with penicillin $G$ benzathine for treatment of incubating syphilis. Ann Intern Med. 1999; 131(6): 434-437.

Trop J Pharm Res, February 2018; 17(2): 349 
6. Hook ER, Martin DH, Stephens J, Smith BS, Smith K. A randomized, comparative pilot study of azithromycin versus benzathine penicillin $G$ for treatment of early syphilis. Sex Transm Dis. 2002; 29(8): 486-490.

7. Riedner G, Rusizoka M, Todd J, Maboko L, Hoelscher M, Mmbando D, Samky E, Lyamuya E, Mabey D, Grosskurth $H$. Single-dose azithromycin versus penicillin $G$ benzathine for the treatment of early syphilis. N Engl J Med. 2005; 353(12): 1236-1244.

8. Hook ER, Behets F, Van Damme K, Ravelomanana N, Leone $P$, Sena AC, Martin D, Langley C, McNeil L, Wolff $M$. A phase III equivalence trial of azithromycin versus benzathine penicillin for treatment of early syphilis. $J$ Infect Dis. 2010; 201(11): 1729-1735.

9. Orle KA, Gates CA, Martin DH, Body BA, Weiss JB. Simultaneous PCR detection of Haemophilus ducreyi, Treponema pallidum, and herpes simplex virus types 1 and 2 from genital ulcers. J Clin Microbiol. 1996; 34(1): 49-54.

10. Lukehart SA, Godornes $C$, Molini BJ, Sonnett $P$, Hopkins $S$, Mulcahy $F$, Engelman J, Mitchell SJ, Rompalo AM, Marra CM, et al. Macrolide resistance in Treponema pallidum in the United States and Ireland. N Engl J Med. 2004; 351(2): 154-158.
11. Hopkins S. Clinical toleration and safety of azithromycin. Am J Med. 1991; 91(3A): 40S-45S.

12. Rolfs $R T$, Joesoef $M R$, Hendershot EF, Rompalo AM, Augenbraun MH, Chiu M, Bolan G, Johnson SC, French $P$, Steen $E$. A randomized trial of enhanced therapy for early syphilis in patients with and without human immunodeficiency virus infection. The Syphilis and HIV Study Group. N Engl J Med. 1997; 337(5): 307-314.

13. Hart G. Syphilis tests in diagnostic and therapeutic decision making. Ann Intern Med. 1986; 104(3): 368376.

14. Kiddugavu MG, Kiwanuka N, Wawer MJ, Serwadda $D$, Sewankambo NK, Wabwire-Mangen F, Makumbi F, Li $X$, Reynolds SJ, Quinn TC, et al. Rakai Study Group. Effectiveness of syphilis treatment using azithromycin and/or benzathine penicillin in Rakai, Uganda. Sex Transm Dis. 2005; 32(1): 1-6.

15. Blandford JM, Gift TL. The cost-effectiveness of singledose azithromycin for treatment of incubating syphilis. Sex Transm Dis. 2003; 30(6):502-508.

16. Paladino JA, Gudgel LD, Forrest A, Niederman MS. Costeffectiveness of IV-to-oral switch therapy: azithromycin vs cefuroxime with or without erythromycin for the treatment of community-acquired pneumonia. Chest. 2002; 122(4):1271-1279. 